\title{
AN EVALUATION OF THE THERMAL AND LUMINOUS ENVIRONMENT OF LAYING HEN AVIARIES EQUIPPED WITH LIGHT-EMITTING DIODE AND COMPACT FLUORESCENT LAMPS AND THEIR EFFECTS ON PRODUCTION AND EGG QUALITY
}

\author{
Priscilla A. P. Ribeiro ${ }^{*}$, Tadayuki Yanagi Junior ${ }^{1}$, Renato R. de Lima ${ }^{1}$, \\ Daniela D. de Oliveira ${ }^{2}$, Lucas H. P. Abreu ${ }^{1}$
}

${ }^{1 *}$ Corresponding author. Universidade Federal de Lavras/ Lavras - MG, Brasil

E-mail: priscilla.ribeiro@ufla.br | ORCID ID: https://orcid.org/0000-0002-6739-3190

\section{KEYWORDS}

thermal environment, artificial lighting, laying hens.

\begin{abstract}
The thermal and luminous conditions in aviaries affect the production and quality of eggs. Thus, the aim of the present study was to evaluate the thermal and luminous environment of commercial laying hen aviaries equipped with compact fluorescent (CF) and light-emitting diode (LED) lamps and their influence on egg production and quality. The study was carried out in two commercial laying hen facilities with similar construction features and management. The first facility was illuminated with CF lamps and the second with LED lamps. The thermal environment was assessed via air temperature, air relative humidity, and enthalpy. The evaluated lamps provided a similar thermal environment in both facilities. The aviary equipped with LED lamps showed higher illuminance than the one equipped with a CF lamp. Production performance was evaluated through feed intake (FI), feed conversion $(\mathbf{F C})$, mortality $(\mathbf{M})$, and laying percentage (LP). Specific gravity (SG) was used to evaluate eggshell quality. The variables related to production performance and eggshell quality of laying hens raised in aviaries equipped with LED lamps were statistically equal (F-test, $p>0.05$ ) to those raised in aviaries equipped with $\mathrm{CF}$ lamps. These results indicate that the replacement of CF lamps with LED lamps does not adversely affect the yield and quality of eggs.
\end{abstract}

\section{INTRODUCTION}

There are several factors involved in the ideal environment for the production of eggs, such as air temperature $\left(\mathrm{t}_{\text {air }}\right.$ ), air relative humidity $(\mathrm{RH})$, air velocity, air quality (concentration of gases such as $\mathrm{NH}_{3}, \mathrm{O}_{2}, \mathrm{CO}_{2}$, and dust), and brightness and sound levels (Tinôco, 2001).

The environment of the intensive rearing system for laying hens directly influences the animal's comfort. Under certain conditions, it is difficult to maintain the thermal balance within the premises, and this affects the expression of the natural behavior of birds, affecting their growth performance (Oliveira et al., 2014).

Stress due to high environmental temperatures is a major cause of losses in the egg production industry. The imbalance in the thermal environment causes serious changes in the physiological system of the birds. In addition to losses in production, such adverse conditions compromise laying performance, resulting in decreased feed intake and physical activity such as a decrease in egg production, an increase in eggs with shell problems like malformation, and even high mortality of birds in the most extreme conditions (Oliveira et al., 2014).

The thermal comfort zone for laying hens reared in aviaries can be characterized by the enthalpy $(\mathbf{H})$ that, through a combination of the $\mathrm{t}_{\mathrm{air}}$ and $\mathrm{RH}$ conditions, quantifies the energy of the air (Barbosa Filho et al., 2007). Based on the comfort limits $\left(15-25{ }^{\circ} \mathrm{C}\right.$ of $\mathrm{t}_{\mathrm{air}}$ and $50-70 \%$ of $\left.\mathrm{RH}\right)$ recommended by Tinôco (2001), the lower and upper limits of enthalpy values considered ideal for laying hens are 28.46 and $60.66 \mathrm{~kJ} \mathrm{~kg}_{\text {dry air }}{ }^{-1}$, respectively.

In addition to the thermal environment, the luminous environment is also important for the breeding of layers and for interfering in the behavior, development,

\footnotetext{
${ }^{1}$ Universidade Federal de Lavras/ Lavras - MG, Brasil.
}

${ }^{2}$ Granja São Jorge/ Lavras - MG, Brasil.

Area Editor: Danilo Florentino Pereira

Received in: 8-8-2019

Accepted in: 10-7-2020 
productive performance, health, and well-being of birds (Parvin et al., 2014).

Apart from affecting the physiology of birds, light and its effects on sight are also related to the behavior and welfare of these animals. The influence of the use of lightemitting diode (LED) lamps and their color variations on the behavior of birds has been previously assessed (Borille et al., 2015; Eich et al., 2016; Senaratna et al., 2016; Li et al., 2018).

The compact fluorescent lamp (CF) is the lighting technology commonly used in Brazilian poultry houses, but recently it has been replaced by the LED lamps. This new lighting system has the advantages of lower power consumption, longer life, and less maintenance. Some authors have evaluated the effects of LED lamps on laying hens and have found no damage to the quality and production of eggs (Borille et al., 2013; Long et al., 2016b; Nunes et al., 2017).

Thermo-luminous conditions can cause losses in the production and quality of eggs. Pereira et al. (2017) verified the correlation between the thermal environment and laying hen performance when the hens were lodged in commercial houses with and without a climatization system. Higher egg production, better external egg quality, and higher feed intake were observed for hens lodged under adequate air temperature and humidity conditions. Birds prefer lower light intensity (5 lux), and laying mostly occurs in illuminances of less than 1 lux (Ma et al., 2016). Nunes et al. (2017) found that laying hens in environments lit with red LED had the same performance and a higher average egg weight than those exposed to fluorescent lamps.

According to North \& Bell (1990), the SG is related to the percentage of shell, indicating the probability of the egg breaking during handling and processing. An increase in SG implies increased shell thickness and strength (Hamilton, 1982).

Assessment of production and eggshell quality can help clarify the effects of the breeding environment on the performance and well-being of the birds (Alves et al., 2007). In this sense, the production, productivity, and quality of eggs are the main interests of egg producers and consumers, and parameters are directly related to factors such as hygiene, sanitation, health, and welfare of animals (Trindade et al., 2007).

Therefore, the objective of this study was to evaluate the thermal and luminous environment of commercial laying hen aviaries equipped with CF and LED lamps and their influence on production and egg quality.

\section{MATERIAL AND METHODS}

This experiment was conducted in commercial laying hen facilities, located in the municipality of Nepomuceno, Minas Gerais, Brazil, with latitude and longitude coordinates of $21^{\circ} 14^{\prime} 09^{\prime}$ S, 45 $14^{\circ} 09^{\prime}$ W $\mathrm{W}$ and altitude of $848 \mathrm{~m}$. The climate is a humid temperate climate (Cwa), according to the Köppen climate classification, with dry winters and rainy summers. The two conventional facilities are equipped with $72 \mathrm{CF}$ lamps $(10 \mathrm{~W})$ and 72 LED lamps $(7 \mathrm{~W})$. The luminous fluxes and color temperatures of the CF and LED lamps were $590 \mathrm{~lm}$ and $6500 \mathrm{~K}$ (white), and $550 \mathrm{~lm}$ and $6400 \mathrm{~K}$ (white), respectively.

The lighting program adopted by the farm is $17 \mathrm{~h}$ light, being $12 \mathrm{~h}$ of daylight, and $5 \mathrm{~h}$ of artificial light. The aviaries used in the present study had identical construction characteristics, with dimensions of $10 \mathrm{~m} \times$ $120 \mathrm{~m}, 4.50 \mathrm{~m}$ ceiling height, east-west orientation, and 2.0-m floor-height in relation to the soil surface. Both facilities had yellow side-wall curtains and $0.65-\mathrm{mm}$ thick (25\% slope) galvanized and hipped metal roof tiles with north and south overhangs, having dimensions of $1.0 \mathrm{~m}$ and $0.5 \mathrm{~m}$ (east-west). Both aviaries had automated feed, drink, and egg collection systems.

Each aviary (open-sided layer house) was equipped with three batteries of four-deck reverse cages spaced 1.0 $\mathrm{m}$ apart, forming four alleys across each facility (Figure 1). Eight Hy-Line W-36 laying hens were housed in each cage (325 $\mathrm{cm}^{2}$ per bird). There were 30,500 laying hens at 22 weeks of age in each aviary at the beginning of the experiment. The experiment was carried out for 33 weeks.

A

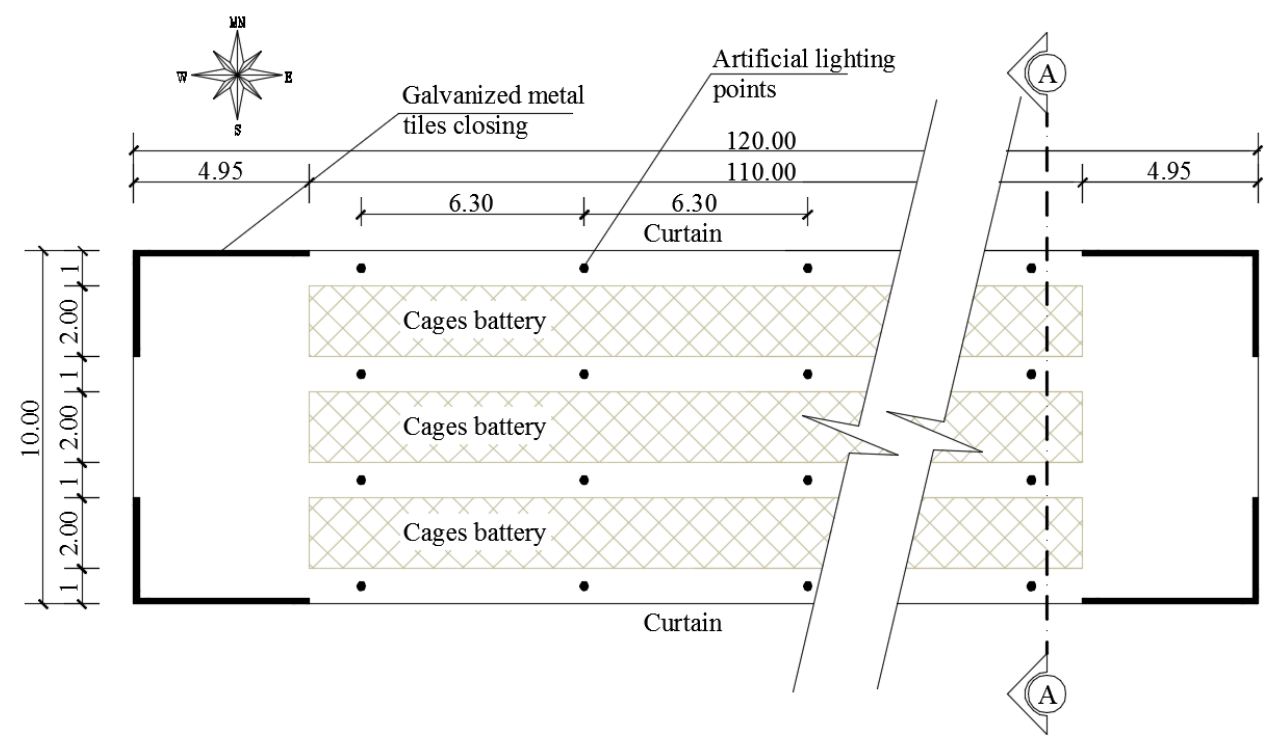


B

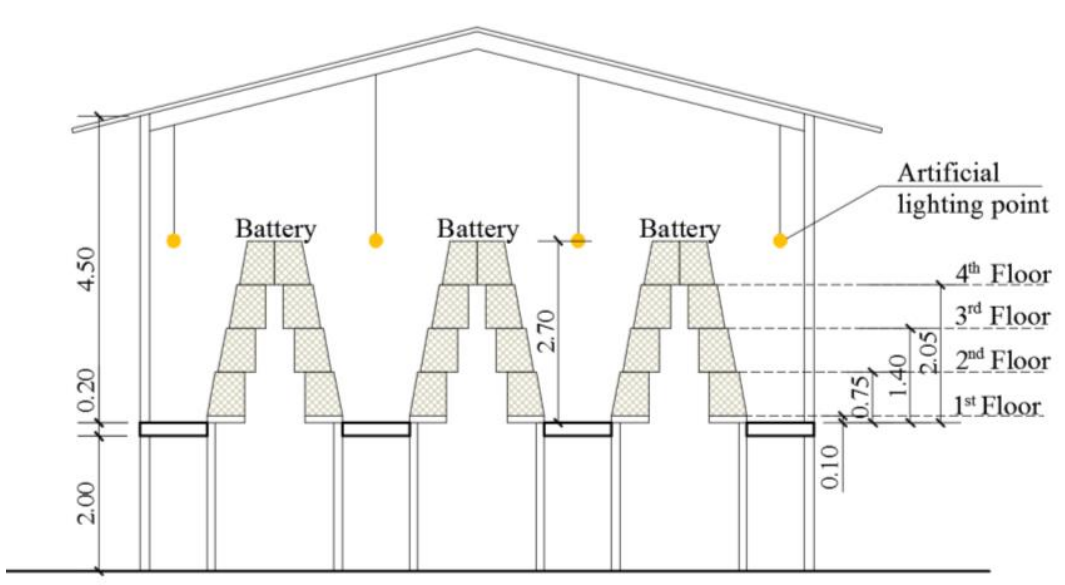

FIGURE 1. Schematic drawing (A) and cross section (B) AA of the aviary (no scale defined). Unit of dimensions: $\mathrm{m}$.

To evaluate the thermal environment, the $t_{\text {air }}$ and $\mathrm{RH}$ data were collected during the experiment in three periods of the day: morning, afternoon, and evening, respectively, at 09:00, 15:00, and 18:00.

The thermal and illuminance measurements were taken at the same time to standardize the statistical analyses. The recording sensors used (accuracy of $\pm 3 \%$ ) were installed in the middle of each lane in each aviary, totaling four sensors per aviary (Figure 2). In addition, a sensor was installed in the outdoor area between the two aviaries evaluated.

A

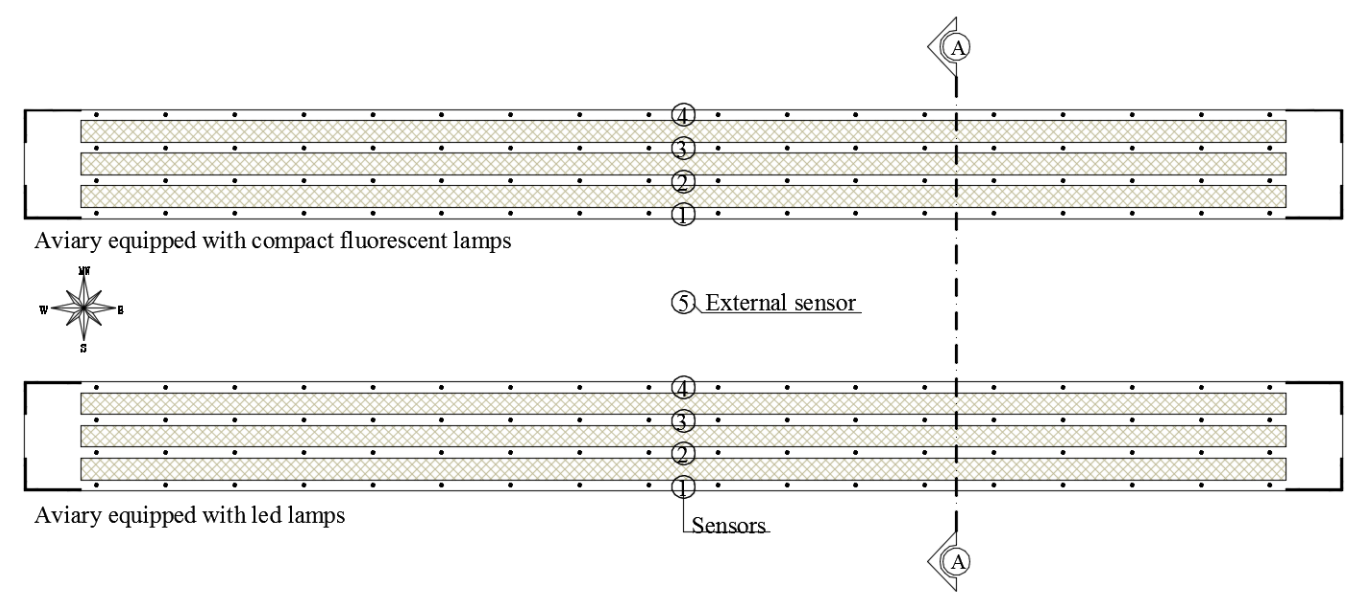

B
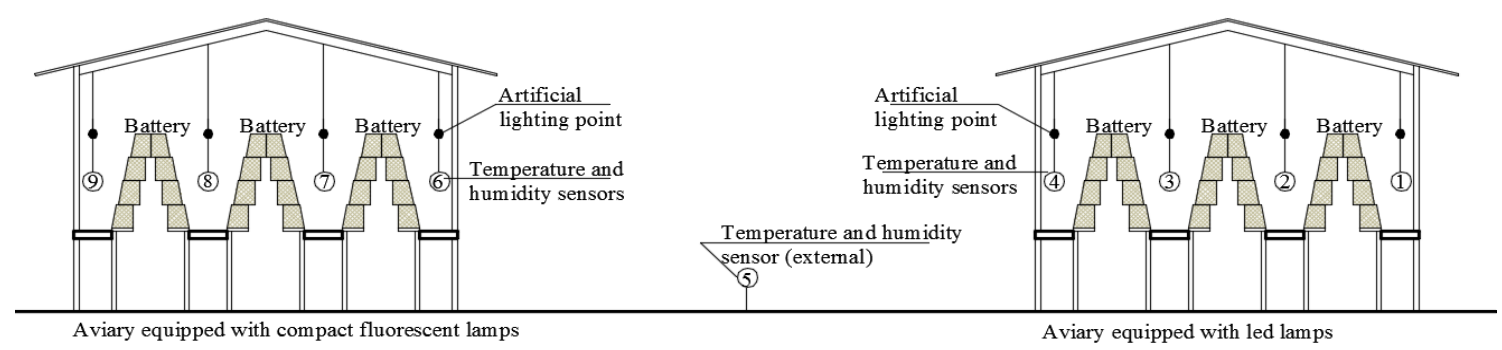

FIGURE 2. Schematic drawing (A) and cross-section AA (B) of the aviaries with the location of the air temperature and humidity sensors.

The enthalpy $\left(\mathrm{H}, \mathrm{kJ} \mathrm{kg}\right.$ dry $\left.^{-1}{ }^{-1}\right)$ was determined using [eq. (1)] as a function of the air dry-bulb temperature $\left(\mathrm{t}_{\text {air }},{ }^{\circ} \mathrm{C}\right)$ and the humidity ratio $\left(\mathrm{W}, \mathrm{kg}_{\text {vapor of water }} \mathrm{kg}_{\text {dry air }}{ }^{-1}\right)$, since it is the most appropriate equation for use in animal studies (Rodrigues et al., 2010).

$$
H=1.006 \cdot t_{\text {air }}+W \cdot\left(2501+1.805 \cdot t_{\text {air }}\right)
$$

In turn, W was calculated using [eq. (2)], which was dependent on the current pressure of water vapor (ea, $\mathrm{kPa})$ and the local atmospheric pressure $\left(\mathrm{P}_{\mathrm{atm}}, \mathrm{kPa}\right)$.

$$
W=0.622 .\left(\frac{\mathrm{en}}{P_{\mathrm{atmm}}}\right)
$$

The illuminance levels were measured to evaluate the luminous environment every $15 \mathrm{~d}$ throughout the experiment, totaling six days of data measurement. Measurements were carried out simultaneously in the two facilities at three times: morning, afternoon, and evening. Digital lux meters (accuracy $\pm 3 \%$ for incandescent lamps and $\pm 5 \%$ for the others) were used. 
The measurements were performed on three sample regions located at the ends and in the middle of the facilities, as shown in Figure 3. At each sampling, the data were collected at five points along the alley, characterizing both regions located under the light sources and those between light sources. At each of these five points, the data were collected at the four levels of the cages at heights of $0.40 \mathrm{~m}, 1.10 \mathrm{~m}, 1.70 \mathrm{~m}$, and $2.40 \mathrm{~m}$ (Figure 4).

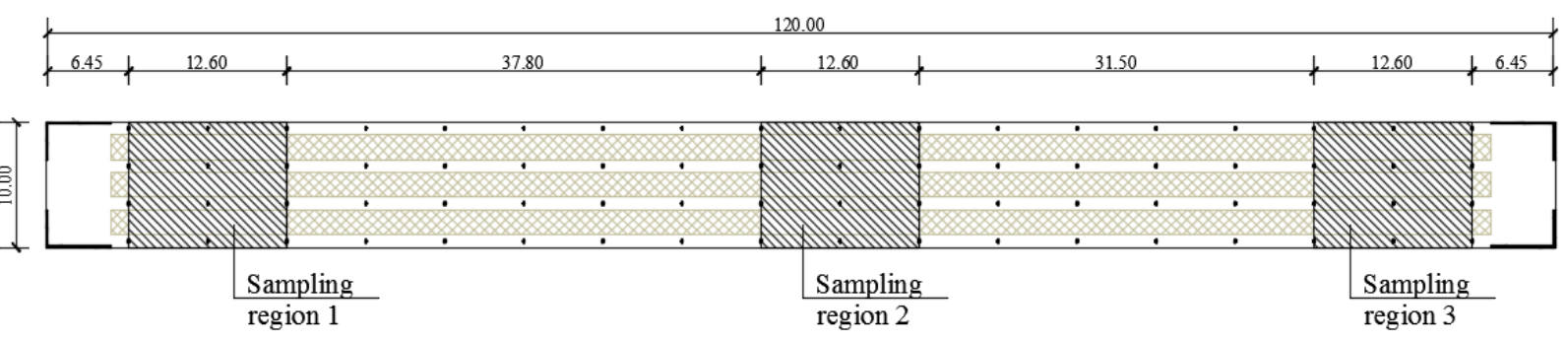

FIGURE 3. Schematic drawing illustrating experimental plots to measure the illuminance inside the aviaries (no defined scale). Unit of dimensions: $\mathrm{m}$.

The handling of the birds was in accordance with standard practices at the commercial facility where the experiment was conducted. The birds received water and feed ad libitum, and feeding was performed three times a day. The automated egg collection was performed daily, with collections in the morning and afternoon.

The productive performance was evaluated through feed intake (FI), feed conversion (FC), mortality (M), and laying percentage (LP), as well as specific gravity (SG), which is used to evaluate eggshell quality.

A

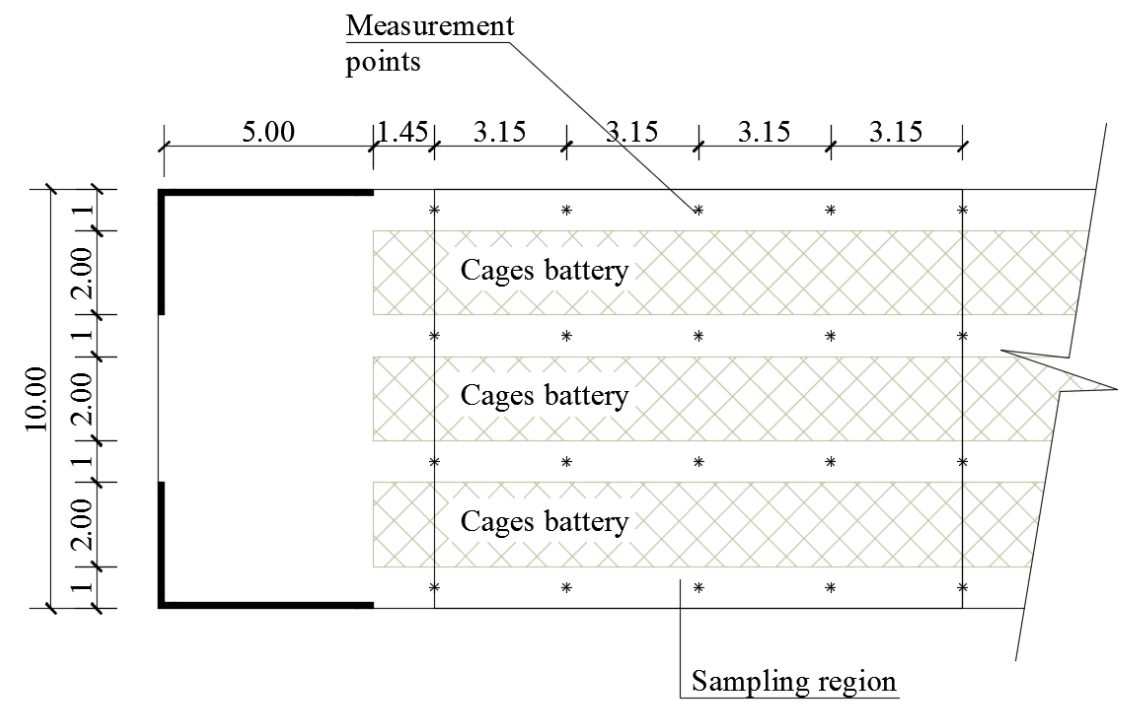

B

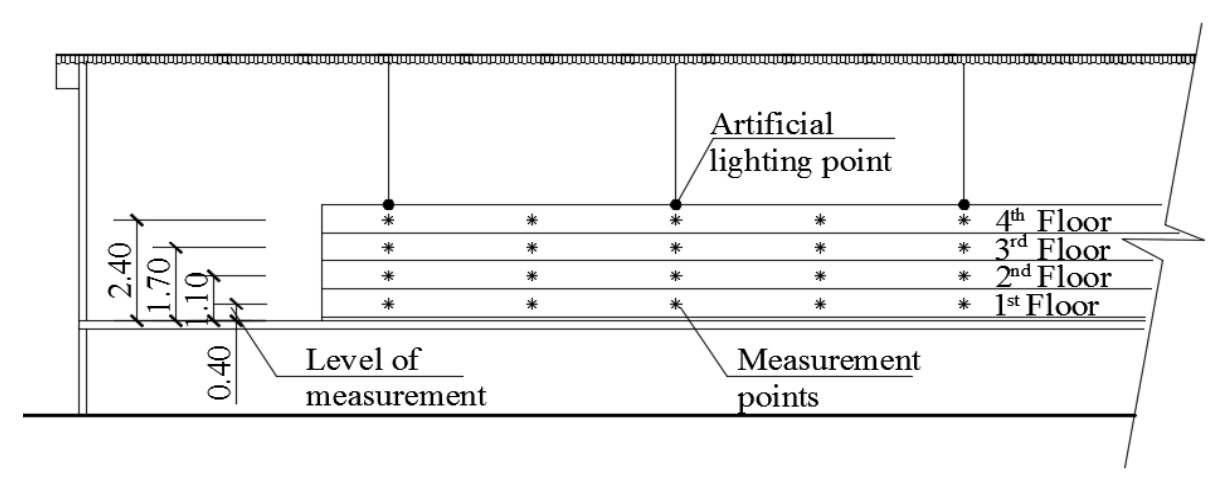

FIGURE 4. Aviary schematic drawing (A) and longitudinal elevation (B) illustrating in detail the points of measurement of illuminance (no defined scale). Unit of dimensions: $\mathrm{m}$. 
The FI value was calculated by subtracting the amount of feed that remained at the end of each week from the amount of feed offered at the start of the week. The average daily consumption, considering the number of dead birds for the week, was calculated. The feed conversion ( $\mathrm{kg}$ feed/dozen eggs) was calculated by dividing the weekly consumption of feed by the accumulated egg production for the week. Egg production was recorded daily, and laying percentage was calculated based on this.

Egg quality was evaluated in 30 eggs randomly sampled weekly from each aviary. Evaluations were made on the day of laying. To assess eggshell quality, SG was measured; this is a method routinely used by researchers and manufacturers (Furtado et al., 2001). The SG was determined by immersing the eggs in salt solutions (water and salt), according to the method proposed by Hamilton (1982).

The experiment followed a randomized complete block design (RCBD). The illuminance variable was analyzed in 18 replicates, and a combination of six days of data measurement and sampling of three regions in the aviary. For the variable enthalpy $(\mathrm{H})$, an analysis was conducted for each period of the day (morning, afternoon, and evening) and the $36 \mathrm{~d}$ corresponding to replicates. The production performance data and specific gravity were evaluated weekly, and each of the 12 weeks was considered a block. Statistical analyses were performed using the SAS software (2012), considering the statistical model given by [eq. (3)]:

$$
y_{i j}=\mu+t_{i}+b_{j}+e_{i j}
$$

Where:

$\mathrm{y}_{\mathrm{ij}}$ is the observation on the portion related to the type of lamp $\mathrm{i}$ in block $\mathrm{j}$;

$\mu$ is the constant inherent in each observation;

$t_{i}$ is the effect of the type of lamp;

$b_{j}$ is the block $j$ effect;

$\mathrm{e}_{\mathrm{ij}}$ is the random error associated with each observation $\mathrm{y}_{\mathrm{ij}}$, and

$$
\mathrm{e}_{\mathrm{ij}} \sim \mathrm{N}(0, \sigma 2) \text {. }
$$

\section{RESULTS AND DISCUSSION}

The values of $t_{\text {air }}$ and $\mathrm{RH}$ observed in the aviaries equipped with CF and LED lamps during the morning, afternoon, and night periods were statistically equal ( $\mathrm{F}$ test, $\mathrm{p}>0.05$ ) (Table 1). Therefore, the effect of the lamps on the thermal environment could be disregarded once similar thermal behaviors were observed in both aviaries. These results corroborate the work of Long et al. (2014), who also did not observe significant differences in the $t_{\text {air }}$ and RH in aviaries equipped with LED and CF lamps.

TABLE 1. Mean values and standard errors (between brackets) of temperature $\left(t_{\text {air }}\right)$ and relative humidity (RH) of the air in the two laying hens aviaries, equipped with compact fluorescent lamps (CF) and LED lamps (LED).

\begin{tabular}{cccc}
\hline Time of day & Type of lamp & $\begin{array}{c}\left.\text { tair }^{\mathbf{0}} \mathbf{C}\right) \\
\text { Mean }\end{array}$ & $\begin{array}{c}\text { RH (\%) } \\
\text { Mean }\end{array}$ \\
\hline \multirow{2}{*}{ Morning } & CF & $19.0( \pm 0.0176)^{\mathrm{a}}$ & $49( \pm 1.4)^{\mathrm{a}}$ \\
\cline { 2 - 4 } & LED & $18.9( \pm 0.0176)^{\mathrm{a}}$ & $51( \pm 1.4)^{\mathrm{a}}$ \\
\hline \multirow{2}{*}{ Afternoon } & CF & $27.4( \pm 0.0229)^{\mathrm{a}}$ & $28( \pm 0.7)^{\mathrm{a}}$ \\
\hline \multirow{2}{*}{ Night } & LED & $27.5( \pm 0.0229)^{\mathrm{a}}$ & $27( \pm 0.7)^{\mathrm{a}}$ \\
\cline { 2 - 4 } & CF & $22.9( \pm 0.0188)^{\mathrm{a}}$ & $35( \pm 1.0)^{\mathrm{a}}$ \\
\hline
\end{tabular}

Means followed by different letters in the column for the morning, afternoon, and evening periods, respectively, differ by $\mathrm{F}$ test at $5 \%$ probability.

According to Tinôco (2001), the upper and lower limits of $t_{\text {air }}$ and $\mathrm{RH}$ for birds in a thermoneutral zone are $15-18{ }^{\circ} \mathrm{C}$ to $22-25{ }^{\circ} \mathrm{C}$ and $50 \%-70 \%$, respectively. According to the Hy-Line W-36 Management Guide (2011), the optimal ranges for $\mathrm{t}_{\text {air }}$ and $\mathrm{RH}$ are $21-24{ }^{\circ} \mathrm{C}$ and $40-60 \%$, respectively.

In both facilities, with respect to the $t_{\text {air }}$ only in the afternoon, the averages did not meet the recommended values. Considering the recommendation of the Tinôco (2001), the RH showed values below the lower comfort limit. Only the facility equipped with the LED lamps presented ideal conditions for thermal comfort in the morning. This result agrees with the Hy-Line W-36 Management Guide (2011), which reports that the RH ideal conditions inside sheds occur mainly in the morning.

Pereira et al. (2017) evaluated the performance of commercial laying hens in automated aviaries with and without system climatization, concluding that the birds present better results in egg production and quality in a more suitable thermal environment.
However, it is important to consider that the experiment was carried out in sided-open facilities without an acclimatization system. The low $\mathrm{RH}$ values observed (Table 1) are due to the implementation of the experiment during the drought period, in addition to the fact that an atypical rainfall deficit occurred in 2014. This drought in the southeast of Brazil was due to climate change caused by a high-pressure system that blocked the Atlantic cold fronts (Mendes, 2014).

The two analyzed facilities showed no statistical difference $(F$ test, $p>0.05)$ for the nightly average $t_{a i r}$, indicating that the evaluated lamps did not affect the thermal condition of the aviaries. Long et al. (2016a) evaluated the technical and operational characteristics of LED and CF lamps in poultry houses for laying and have observed that these practices are unlikely to entail room heating, a condition that was observed in this research.

Due to the importance of the combined effect of $t_{\text {air }}$ and $\mathrm{RH}$ for the condition of environmental thermal comfort, the thermodynamic property $\mathrm{H}$ was analyzed 
(Table 2). Considering the ideal threshold values of enthalpy for laying hens, 28.46 and $60.66 \mathrm{~kJ} \mathrm{~kg}_{\mathrm{dry}}$ air $^{-1}$, calculated based on the comfort limits $\left(15\right.$ to $25^{\circ} \mathrm{C}$ of $\mathrm{t}_{\text {air }}$ and 50 to $70 \%$ of $\mathrm{RH}$ ) recommended by Tinôco (2001), for all measurement times, the $\mathrm{H}$ values were within the comfort interval. Comparing the $\mathrm{H}$ values in aviaries equipped with $\mathrm{CF}$ and LED lamps during the morning, afternoon, and evening periods revealed no significant differences ( $\mathrm{F}$ test, $\mathrm{p}>0.05$ ), indicating that the use of these lamps did not affect the thermal conditions of the aviaries. These results are similar to those obtained for the variables $t_{\text {air }}$ and $\mathrm{RH}$.

TABLE 2. Means and standard errors (between brackets) of enthalpy for morning, afternoon and evening periods for the aviaries equipped with compact fluorescent lamps (CF) and LED lamps (LED).

\begin{tabular}{|c|c|c|}
\hline & $\begin{array}{c}\text { Enthalpy (kJ kgdry air } \\
\left.\text { kJ kg }{ }_{\text {dry air }}^{-1}\right)\end{array}$ & \\
\hline \multirow{2}{*}{ Time of day } & \multicolumn{2}{|c|}{$\begin{array}{ll}\text { Type of lamp } \\
\end{array}$} \\
\hline & $\mathbf{C F}$ & LED \\
\hline Morning & $36.2( \pm 0.49)^{\mathrm{a}}$ & $36.7( \pm 0.49)^{\mathrm{a}}$ \\
\hline Afternoon & $43.2( \pm 0.40)^{\mathrm{a}}$ & $43.4( \pm 0.40)^{\mathrm{a}}$ \\
\hline Night & $36.8( \pm 0.44)^{\mathrm{a}}$ & $37.4( \pm 0.44)^{\mathrm{a}}$ \\
\hline
\end{tabular}

Means followed by different letters in the lines differ by $\mathrm{F}$ test at $5 \%$ probability.

Although the two facilities had the same number of installed lamps and lamp types having the same luminous flux, the aviary equipped with the LED lamps had higher illuminance values as compared to the facility equipped with the CF lamps (F-test, $\mathrm{p}<0.05$ ) (Table 3). This may be due to the fact that directional luminous flux is a characteristic of LED lamps, and, in the case of the lamps evaluated, the beam's angle was $120^{\circ}$. Thus, the repositioning of the lamps in the aviary may decrease the average illuminance.

The measured intensities were above the minimum of 5 lux value recommended for laying hen aviaries (North \& Bell, 1990); however, the Hy-Line W-36 Management Guide (2016) recommends that the light intensity should be between 5 and 15 lux for birds over 29 days old.

According to Jácome et al. (2014), illuminance of more than 10 lux does not lead to any benefit and may impair production. However, Yildiz et al. (2006) found that luminous intensity between 35 and 55 lux improved the yield and quality of eggs. It is noteworthy that the minimum illuminance for the physiological stimulus for the birds to respond to changes in photoperiod is 2 lux (Garner et al., 2012; Morris, 2004).

TABLE 3. Means and standard errors (between brackets) of illuminance in artificial lighting period (nighttime) for commercial laying hen facilities equipped with compact fluorescent lamps (CF) and LED lamps (LED).

\begin{tabular}{cc}
\hline Type of lamp & Night illuminance (lux) \\
\hline CF & $16( \pm 0.5)^{\mathrm{a}}$ \\
\hline LED & $28( \pm 0.5)^{\mathrm{b}}$ \\
\hline
\end{tabular}

Means followed by different letters differ by the $\mathrm{F}$ test at $5 \%$ probability.
Ma et al. (2016) evaluated the effectiveness of light intensity and laying preferences at five different levels: <1, $5,15,30$, and 100 lux. The birds spent most of their time $(45.4 \%)$ in 5 lux and showed preference for illuminances $<1$ lux, and $61.90 \%$ of the eggs were laid in this condition.

The FI was not statistically influenced ( $F$ test, $\mathrm{p}>$ $0.05)$ by the type of lamps during the study period, corroborating the results of Nunes et al. (2017), Liu et al. (2017), and Kamanli et al. (2015). According to Borille et al. (2013), this indicates that the birds have similar visual sensitivity for the two light sources tested, and that this does not change their feeding behavior. Similarly, FC and $\mathrm{M}$ were not influenced by the type of lamp (F-test, $\mathrm{p}>$ 0.5). Long et al. (2016a) evaluated the use of fluorescent and LED lamps in laying hen aviaries and found no differences in egg weight, productivity, FI, and M, but the birds housed under the light of fluorescent lamps showed better FC. The authors emphasize the need for further research under commercial conditions to assess the actual conditions of production and use of this technology, since most experiments are conducted in the laboratory.

There was no statistical difference ( $F$ test, $p>0.05$ ) between the lamp types for the LP and SG variables (Table 4). Therefore, the difference between the illuminance levels offered by the two illumination systems did not influence the production and egg quality.

TABLE 4. Average and standard errors (between brackets) of feed intake (FI), feed conversion (FC), mortality (M), laying percentage (LP) and specific gravity (SG) for aviaries equipped with compact fluorescent lamps (CF) and LED lamps (LED).

\begin{tabular}{cccccc}
\hline Type of lamp & $\begin{array}{c}\text { FI } \\
(\mathbf{g})\end{array}$ & $\begin{array}{c}\text { FC } \\
(\mathbf{k g} \text { feed / dz eggs })\end{array}$ & $\begin{array}{c}\text { M } \\
(\boldsymbol{\%})\end{array}$ & $\begin{array}{c}\text { LP } \\
(\boldsymbol{\%})\end{array}$ & SG \\
\hline CF & $80.3( \pm 6.0)^{\mathrm{a}}$ & $1.19( \pm 0.07)^{\mathrm{a}}$ & $0.05( \pm 0.01)^{\mathrm{a}}$ & $83.36( \pm 6.40)^{\mathrm{a}}$ & $1086.97( \pm 0.77)^{\mathrm{a}}$ \\
\hline LED & $80.2 \pm 6.0^{\mathrm{a}}$ & $1.20( \pm 0.07)^{\mathrm{a}}$ & $0.05( \pm 0.01)^{\mathrm{a}}$ & $82.08( \pm 6.08)^{\mathrm{a}}$ & $1086.64( \pm 0.66)^{\mathrm{a}}$ \\
\hline
\end{tabular}

Means followed by different letters differ by the $\mathrm{F}$ test at $5 \%$ probability. 
The use of CF and LED lamps did not influence the LP ( $F$ test, $p>0.05$ ), corroborating the results of other studies (Borille et al., 2013; Long et al., 2016a; Liu et al., 2018).

Long et al. (2016b) evaluated the weight and storage time of eggs laid by hens of different ages and reared in facilities equipped with LED and CF lamps. The results showed that LED light provided a higher egg weight at 27 weeks of age and thicker eggshell at 40 weeks, but with a lower weight. No quality differences were noted over the $62 \mathrm{~d}$ storage period, indicating that LED light did not influence the storage period.

According to Oliveira et al. (2014), when the birds are in environments within the thermal comfort zone, there is a positive effect on the production and egg quality parameters. In this condition, the birds have better utilization of calcium and other nutrients found in the feed, and this is essential in the distribution of the nutrients on the egg surface during their formation. In the experiment, once the birds were within their thermal neutral zone and that the average temperature values observed during the experiment were located within the critical limits established in the literature, the birds were able to express achieve their full productive potential.

Despite the illuminance differences observed between the two types of lamps, it was no statistically seen significant difference ( $F$ test, $p>0.05$ ) between the SG averages that were of 1086.97 and 1086.64 for $\mathrm{CF}$ and LED lamps, respectively. Whereas the parameter evaluated, SG, is an indicator of the eggshell quality, it can be concluded that the type of lamp there was had no effect of the type of lamp on the external egg quality, and the lower illuminance values can be adopted without any prejudice effects.

The results found for SG are in accordance with those observed by Alves et al. (2007), who evaluated quality of eggs produced in the cage systems.

\section{CONCLUSIONS}

In conclusion, the findings from this study have shown that LED-based technology can replace FC lamps, with similar effects on indoor aviary thermal environments and the productive performance and eggshell quality of laying hens.

\section{ACKNOWLEDGEMENTS}

The authors express their thanks to CAPES, FAPEMIG, and CNPq for their financial support and to the Aviário Santo Antônio group for providing their facilities for this research.

\section{REFERENCES}

Alves SP, Silva IJO, Piedade SMS (2007) Avaliação do bem-estar de aves poedeiras comerciais: efeitos do sistema de criação e do ambiente bioclimático sobre o desempenho das aves e a qualidade de ovos. Revista Brasileira de Zootecnia 36(5):1388-1394. DOI: http://dx.doi.org/10.1590/S1516-35982007000600023
Barbosa Filho JAD, Silva IJO, Silva MAN, Silva CJM (2007) Avaliação dos comportamentos de aves poedeiras utilizando sequência de imagens. Engenharia Agrícola 27(1):93-99. DOI: http://dx.doi.org/10.1590/S010069162007000100002

Borille R, Garcia RG, Royer AFB, Santana MR, Colet S, Nääs IA, Caldara FR, Almeida Paz ICL, Rosa ES, Castilho VAR (2013) The use of light-emitting diodes (LED) in commercial layer production. Revista Brasileira de Ciência Avícola 15(2):135-140. DOI:

http://dx.doi.org/10.1590/S1516-635X2013000200009

Borille R, Garcia RG, Nääs IA, Caldara FR, Santana MR (2015) Monochromatic light-emitting diode (LED) source in layers hens during the second production cycle. Revista Brasileira de Engenharia Agrícola e Ambiental 19(9):877881. DOI: http://dx.doi.org/10.1590/18071929/agriambi.v19n9p877-881

Eich MRS, Garcia RG.; Nääs IA, Caldara F, Borille R, Royer AFB, Sgaviolli S (2016) Behavior of Broilers Reared under Monochromatic and Fluorescent Light Sources. International Journal of Poultry Science 15(3):96102. DOI: 10.3923/ijps.2016.96.102

Furtado IM, Oliveira AIG, Ferreira DF, Oliveira BL, Rodrigues PB (2001) Correlação entre medidas da qualidade da casca e perda de ovos no segundo ciclo de produção. Ciência e Agrotecnologia 25(3):654-660

Garner JP, Kiess AS, Mench JA, Newberry RC, Hester PY (2012) The effect of cage and house design on egg production and egg weight of White Leghorn hens: An epidemiological study. Poultry Science 91(7):1522-1535. DOI: https://doi.org/10.3382/ps.2011-01969

Hamilton, RGM (1982) Methods and factors that effect the measurement of egg shell quality. Poultry Science 61(10):2022-2039. DOI: https://doi.org/10.3382/ps.0612022

Hy-line (2016) Manual de padrões e de desempenho Hyline W-36. Available: http://www.hylinedobrasil.com.br. Accessed May 6, 2019.

Hy-line (2011) Manual de padrões e de desempenho Hyline W-36. Available: http://www.hylinedobrasil.com.br. Accessed Abr 23, 2015.

Jácome IMTD, Rossi LA, Borille, R (2014) Influence of Artificial Lighting on the Performance and Egg Quality of Commercial Layers: a Review. Brazilian Journal of Poultry Science, 16(4): 337-344. DOI: http://dx.doi.org/10.1590/1516-635X1604337-344

Kamanli S, Durmus I, Demir S, Tarim B (2015) Effect of different light sources on performance and egg quality traits in laying hens. European Poultry Science 79:1-7. DOI: http://dx.doi.org/10.1399/eps.2015.109

Li G, Li B, Zhao Y, Shi Z, Liu Y, Zheng W (2018) Layer pullet preferences for light colors of light-emitting diodes. Animal 13(6):1245-1251. DOI: http://dx.doi.org/10.1017/S1751731118002537 
Liu K, Xing H, Chai L (2017) Choice between LED and Fluorescent Lights by Pullets and Laying Hens. In: Conference Proceedings and Presentations. St. Joseph, Agricultural and Biosystems Engineering, paper number 1700029. DOI: http://dx.doi.org/10.13031/aim.201700029

Liu K, Xin H, Sekhon J, Wang T (2018) Effect of fluorescent vs. poultry-specific light-emitting diode lights on production performance and egg quality of W-36 laying hens. Poultry Science 97(3):834-844. DOI: https://doi.org/10.3382/ps/pex371

Long H, Zhao Y, Wang T, Ning Z, Xin H (2016a) Effect of light-emitting diode vs. fluorescent lighting on laying hens in aviary hen houses: Part 1 - Operational characteristics of lights and production traits of hens. Poultry Science 95(1):1-11. DOI: https://doi.org/10.3382/ps/pev121

Long H, Zhao Y, Xin H, Hansen H, Ning Z, Wang T (2016b) Effect of light-emitting diode (LED) vs. fluorescent (FL) lighting on laying hens in aviary hen houses: Part 2-Egg quality, shelf-life and lipid composition. Poultry Science 95(1):115-124. DOI: https://doi.org/10.3382/ps/pev306

Long H, Zhao Y, Wang T, Xin H, Ning, Z (2014). Comparative evaluation of light emitting diode (LED) vs fluorescent (FL) lighting in commercial aviary hen houses. Agricultural and Biosystems Engineering Conference Proceedings and Presentations: 383 . DOI: https://doi.org/10.13031/aim.20141893157

Ma H, Xin H, Zhao Y, Li B, Shepherd A, Alvarez I (2016) Assessment of lighting needs by W-36 laying hens via preference tests. Animal. 10(4):671-680. DOI: https://doi.org/10.1017/S1751731115002384

Mendes LFR (2014) Considerações acerca da geração hidroelétrica fluminense a partir da crise hídrica do estado de São Paulo. Boletim do Observatório Ambiental Alberto Ribeiro Lamego 8(1):35-49. DOI: https://doi.org/10.5935/2177-4560.20140003

Morris TR (2004) Environmental control for layers. World's Poultry Science Journal 60(2): 163-175. DOI: https://doi.org/10.1079/WPS200310

North MO, Bell DD (1990) Commercial Chicken Production Manual. New York, Van Nostrand Reinhold, 913p.

Nunes KC, Garcia RG, Nääs IA, Eyng C, Caldara F, Sgavioli S, Rombola LG (2017) Iluminação artificial com fitas de LED em substituição à lâmpada fluorescente para poedeiras comerciais. Archivos de Zootecnia 66 (253): 15. DOI: https://doi.org/10.21071/az.v66i253.2118
Oliveira DL, Nascimento JWB, Camerini NL, Silva R, Furtado DA, Araújo TGP (2014) Desempenho e qualidade de ovos de galinhas poedeiras criadas em gaiolas enriquecidas e ambiente controlado. Revista Brasileira de Engenharia Agrícola e Ambiental 18(11):1186-1191. DOI: http://dx.doi.org/10.1590/1807-1929/agriambi

Parvin R, Mushtaq MMH, Kim MJ, Choi HC (2014) Light emitting diode (LED) as a source of monochromatic light: a novel lighting approach for behaviour, physiology and welfare of poultry. World's Poultry Science Journal 70(3):543-556. DOI: https://doi.org/10.1017/S0043933914000592

Pereira DF, Kodaira V, Bueno LGF (2017) Technical feasibility of the acclimatization system in aviary of posture: a case study. Journal of the Brazilian Association of Agricultural Engineering 37(5): 855-866. DOI: http://dx.doi.org/10.1590/1809-4430

Rodrigues VC, Silva IJO, Vieira FMC, Nascimento ST (2010) A correct enthalpy relationship as thermal comfort índex for livestock. International Journal Biometeorology 55(3):455-459. DOI: https://doi.org/10.1007/s00484-010$0344-\mathrm{y}$

SAS Institute (2012) SAS/STATTM SAS user's guide for windows environment. Cary, SAS Institute, 9.3 ed.

Senaratna D, Samarakone TS, Gunawardena WWDA (2016) Red Color Light at Different Intensities Affects the Performance, Behavioral Activities and Welfare of Broilers. Asian-Australasian Jounal of Animal Sciences 29(7):1052-1059. DOI: https://doi.org/10.5713/ajas.15.0757

Tinôco IFF (2001) Avicultura industrial: Novos conceitos de materiais, concepções e técnicas construtivas disponíveis para galpões avícolas brasileiros. Revista Brasileira de Ciência Avícola 3(1):1-26. DOI: http://dx.doi.org/10.1590/S1516-635X2001000100001

Trindade JL, Nascimento JWB, Furtado DA (2007) Qualidade do ovo de galinhas poedeiras criadas em galpões no semi-árido paraibano. Revista Brasileira de Engenharia Agrícola Ambiental 11(6):652-657. DOI: http://dx.doi.org/10.1590/S1415-43662007000600015

Yildiz A, Lançin E, Hayirli A, Macit M (2006) Effects of cage location and tier level with respect to light intensity in semiconfined housing on egg production and quality during the late laying period. Journal Applied Poultry Research 15(3):355-361. DOI: https://doi.org/10.1093/japr/15.3.355 